\title{
Enhancing Labour Productivity by Introducing Usage of Limited Electrical Gadgets During Working Hours
}

\author{
R. Velanganni, G. Santhoshkumar, S. Robin
}

\begin{abstract}
Well-being is considered a subjective concept because it applies to time and space. Improvements have an effect on the process. As a consequence, possible changes in welfare material continue to change with time and space. It has also been noted that the definition of welfare varies from country to country and from site to site.

Second, welfare is a positive concept that, if a minimum standard of living is to be established, it would require certain lowest acceptable circumstances of existence, both biologically and socially. Thus, when this is defined, it is necessary to take care of the components of healthcare in terms of health, food, clothing, housing, medical assistance, insurance and so on.

However, as a definition, labor welfare has both positive and negative aspects, it deals with the providing of opportunity that allow the worker and his family to lead a good life, both socially and personally, and on the negative, it provides opportunities for unpleasant consequences and labor problems.
\end{abstract}

\section{INTRODUCTION}

The term welfare brings in certain ideas, implying well-being, good health, satisfaction, stability and the human development resources. The idea of welfare was a general concept concerning the physical, psychological, moral and social well-being of the person. The basic concept of well-being is the wellbeing of man, his family and his society. It's a combination of three things in the way that altogether of these elements work organized. and complement each other independently.

\section{A. The Concept}

The definition of labor varies from country to country, from industry to industry and from time to time and from region to region. It also depends on the kind of problems faced by society that are shaped by age group, sex, socio-cultural background, economic status and the level of education of employees in different areas. The use of the theory of social rights as a driving force for every worker and for those who are involved in it.[1]-[5]

Revised Manuscript Received on December 30, 2019.

R. Velanganni, Assistant professor, Department Of Science \& Humanities, Bharath Institute of Higher Education and Research ,Chennai, India. .Email velangannijose78516@gmail.com

G. Santhoshkumar, Assistant professor, Department Of Science \& Humanities, Bharath Institute of Higher Education and Research ,Chennai, India. .Email santhoshravi671026@gmail.com

S. Robin, Assistant professor, Department Of Science \& Humanities, Bharath Institute of Higher Education and Research ,Chennai, India.

\section{B. Definition}

There could not be just one single definition to find universal acceptance. The simplest of all could be to understand that labour welfare as "efforts to make life worth living for worker “. The Social Sciences Welfare Encyclopedia is characterized as a voluntary effort by employers to create, within the established industrial system, the working and sometimes living and cultural conditions of employees beyond what is required by law, the norms of the industry and the market conditions.."

Another description on the welfare of workers describes it as ' which covers all the efforts made by workers to support their staff above and beyond the basic standard of working conditions laid down in the factory act and above and beyond the provisions of social regulations providing for the prevention of accidents, old age, poverty and sickness. '

\section{Statement of Problem}

This study is important to find out how labor welfare facilities significantly influence the level of employee satisfaction and If statutory and non-legislative social welfare services are good indicators of employee satisfaction.

\section{NEED OF THE STUDY}

1. The dynamics workers and supervisors relationship play a vital role with respective employee satisfaction.

2. The labor welfare measures provided in an organization affect the attitude of employees towards work.

3. To promote the employee's welfare measures like recreation facilities

A. Purposes of the analysis

1. To research steps for the welfare of workers.

2. To identify the attributes of welfare measures leading to employee satisfaction.

3. To evaluate the relationship between labour welfare measures and employee satisfaction.[6]-[10]

\section{SCOPE OF THE STUDY}

1. The scope of the study is to understand employee welfare in 


\section{Enhancing Labour Productivity by Introducing Usage of Limited Electrical Gadgets During Working}

Hours

the company since employee welfare is very important, the study limitations more on types of welfare provided to the employees within and outside the organization.

2. The scope of the study is limited to labor welfare schemes.

3. This study helps to assist top management to pick up the measures for labor welfare in approving for employees.[11]-[15]

\section{RESEARCH METHODOLOGY}

The descriptive methodology is used which is single cross-sectional in nature, this method is helpful to know the measures taken for the welfare of the labors in both statutory and non statutory benefits which lead to employee satisfaction

A.Primary data: interview method, direct observation and also by a structured questionnaire

B.Secondary data: available books, articles, websites, and journals

C.Sample design- sample technique used in simple random sampling, convenience sampling technique

D.Sample size: The sample size of 250 labors was chosen from this industry

Primary data: interview method, direct observation and also by a structured questionnaire

$\square$ Secondary data: available books, articles, websites, and journals

$\square$ Sample design- sample technique used in simple random sampling, convenience sampling technique [16]-[20]

\section{LIMITATIONS}

1. The laborers were not able to express their opinion in front of the superiors and co-workers.

2. Unable to meet all the due to lack of time, the researcher labor of concern.

3. Bias from the part of respondents was another limitation of the study[21]-[25]

\section{LITERATURE REVIEW}

Meenakshi and Yadav Kumar (2013) The paper looks to the authorities at work safety initiatives under shifting monetary conditions. This examination means that workers should be provided with these workplaces It was the product of additional care among staff. With a specific final objective of preserving good current relations and stability in associations, the corporate division must concentrate on these steps in an effective manner, keeping in mind the opinion of the establishments on social welfare figures..

Keerthisriya Dr. Panatulamurali (Krishna 2014) The results indicate that the overall level of awareness of the various provisions of the Factory Act is not a high level, but rather an acceptable level, provided by the industries, of all accounts necessary among the employees. Health and health assessed by the company that keeps workers happy.
R Santana Krishnan (2015) In this study, humane requirements and application in any country influence social protection practices. In India, before health and other regulations were implemented, the condition of employment was bleak, exploitation of child labor, long-term work, terrible cleanliness and lack of appearance of well-being initiatives was common. Of Existence of industrial plants in India. This article details initiatives and services for social security.

K. Logasakthi\& K. Raja Gopal (2013)This investigator sees the welfare actions taken in the combined sector, the standard of success of the leader and the overall nature of the working life of the staff and employees. The collection of data was done on the timeline. Now and again, the distinct meeting was required around that time to close the questionnaire, to break down the compiled information. the analyst utilized basic rate examination.

\section{A. Statistical Hypothesis}

1. H1 - There was no mean difference in employee satisfaction score among the demographic classification of the employees.

2. H2 - There was no mean difference in labor facility score among the demographic classification of the employees.

3. H3 - There was no correlation between employee satisfaction and welfare facilities

\section{RESULTS \& DISCUSSION}

1. There was no significant mean difference in the employee satisfaction scores among difference age ways

2. There was no significant mean difference in the employee satisfaction scores among difference between male and female employees

3. There was the significant mean difference in the employee satisfaction scores among there is no difference between employee qualification

4. There was no significant mean difference in the employee satisfaction scores among difference experience of employees 5. There was no significant mean difference in the employee satisfaction scores among difference marital status of employees

6. 6. There was no substantial mean difference between employee compensation gaps in employee satisfaction scores 7. There was no significant mean difference in the employee satisfaction scores among the difference between job designation of the employees

8. There was a significant mean difference in employee facilities score among different experience in employees

9. There exist a positive correlation between employees satisfaction and facility it is not significant

10. There exist a significant positive correlation between employee satisfaction and statutory facilities

11. There exist a significant positive correlation between employee satisfaction and non-statutory facilities 


\section{SUGGESTIONS}

1. All employees should actively participate in welfare activities

2. The superior need to have a good rapport with their subordination to build a healthy relations The organization need to provide a better and ergonomically sitting arrangement to the workers

3. The organizations need to take care that the workers get paid on specified due dates to avoid any contingency

4. The organization need to provide workers with good employee engagement activity and recreational facilities so have to retain the enthuse in the worker.

\section{CONCLUSION}

The health facilities provide their employees with better working conditions and a better living environment, which, as an improvement in moral satisfaction, is committed to the purpose of the company.. From the study there is no significant difference between the employee satisfaction and facilities and there is a positive relationship between the employee satisfaction and statutory and with the non-statutory facilities. From the study, it is found that some of the workers are not satisfied with the relationship with their superior building good so the organization should take care so that healthy communication occurs between the workers and superior. Most of the workers are neutral in their response with respect sitting arrangements in the organization. According to this study some of the workers expecting to improve existing welfare facilities within the organization.

\section{REFERENCES}

1. Vasanthi, S. \& Rabiyathul Basariya, S. 2019, "Influence of value analysis and cross training in industry", International Journal of Engineering and Advanced Technology, vol. 8, no. 6, pp. 1810-1811.

2. Velvizhi, R., Sri Gowtham, S. \& Jeya Priya, D. 2019, "Examination of early feedbacks for effective product retailing on E-commerce websites", International Journal of Engineering and Advanced Technology, vol. 8, no. 6 Special Issue 2, pp. 703-706.

3. Anuradha, C., Pothumani, S. \& Kavitha, R. 2019, "A novel method towards E-commerce", International Journal of Engineering and Advanced Technology, vol. 8, no. 6 Special Issue 2, pp. 535-538.

4. Thomas, J. \& Rabiyathul Basariya, S. 2019, "A study on the issues of financial ratio analysis", Indian Journal of Public Health Research and Development, vol. 10, no. 3, pp. 1079-1081.

5. Ramachandran, S. \& Rabiyathul Basariya, S. 2019, "Online marketing - study on customer satisfaction and relationship", Indian Journal of Public Health Research and Development, vol. 10, no. 3, pp. 1072-1078.

6. Priya, R., Vinothini, G. \& Cor Jesu, C.D. 2019, "The mentor-protégé relationship for professional growth", Journal of Advanced Research in Dynamical and Control Systems, vol. 11, no. 9 Special Issue, pp. 1110-1119.

7. Jannifer Rani, N., Bina Pani, S. \& Nimisha, N.S. 2019, "A study on money back polices available in LIC", Journal of Advanced Research in Dynamical and Control Systems, vol. 11, no. 9 Special Issue, pp. 833-839.

8. Saillaja, V., Jhansi Rani, K. \& Catherine, R. 2019, "Global marketing management planning and organization", Journal of Advanced Research in Dynamical and Control Systems, vol. 11, no. 9 Special Issue, pp. 489-493.

9. Saillaja, V., Jhansi Rani, K. \& Catherine, R. 2019, "The new phase of marketing information system", Journal of Advanced Research in

Dynamical and Control Systems, vol. 11, no. 9 Special Issue, pp. 482-488.

10. Thoufiqulla \& Raju, D.V. 2019, "Perception of indian investor towards investment in mutual funds with special reference to mip funds", Journal of Advanced Research in Dynamical and Control Systems, vol. 11, no. 5, pp. 177-183.

11. Jasmine, K.R.M. \& Basariya, S.R. 2018, "A study on the customers benefits on mutual funds", International Journal of Civil Engineering and Technology, vol. 9, no. 4, pp. 45-48.

12. Vasanthi, S. \& Basariya, S.R. 2019, "Pros and cons of on the job training versus off the job training", International Journal of Scientific and Technology Research, vol. 8, no. 10, pp. 671-674.

13. Pavithra, J. \& Ganesan, M. 2016, "A study on awareness and impact of micro-financial schemes", International Journal of Applied Business and Economic Research, vol. 14, no. 8, pp. 5449-5460.

14. Pavithra, J., Dilli Babu, P. \& Ambuli, T.V. 2014, "A study on budgetary control at Maruti Service Masters, Chennai", International Journal of Applied Business and Economic Research, vol. 12, no. 2, pp. 151-161.

15. Gunaraja, T.M. \& Venkatrama Raju, D. 2018, "Determining factors of organisational climate with reference to leadership styles", International Journal of Mechanical Engineering and Technology, vol. 9, no. 9, pp. 1327-1332.

16. Gunaraja, T.M. \& Venkatrama Raju, D. 2018, "The role of job satisfaction and training of employees in determining organisational climate of a selected industry", International Journal of Civil Engineering and Technology, vol. 9, no. 8, pp. 1266-1269.

17. Aarathy, T.S. \& Raju, D.V. 2018, "Performance appraisal and its effects on employees with respect to it sector in Chennai city", International Journal of Civil Engineering and Technology, vol. 9, no. 6, pp. 1535-1538.

18. Aarathy, T.S. \& Raju, D.V. 2018, "Employee perception towards performance appraisal system in IT sector", International Journal of Mechanical Engineering and Technology, vol. 9, no. 5, pp. 131-135.

19. Porselvi, W., Jublee, D. \& Sivanesan, G. 2018, "A study on factors influencing adoption of technology and innovation in banking industry, tamilnadu, India", International Journal of Mechanical Engineering and Technology, vol. 9, no. 5, pp. 789-800.

20. Akessa, G.M. and Dhufera, A.G., 2015. Factors That Influences Students Academic Performance: A Case of Rift Valley University, Jimma, Ethiopia. Journal of Education and Practice, 6(22), pp.55-63.

21. Miller, G. and Shih, C.C., 1999. A faculty assessment of the academic rigor of on-and off-campus courses in agriculture. Journal of Agricultural Education, 40, pp.57-65.

22. Tsinidou, M., Gerogiannis, V. and Fitsilis, P., 2010. Evaluation of the factors that determine quality in higher education: an empirical study. Quality Assurance in education, 18(3), pp.227-244.

23. Farooq, M.S., Chaudhry, A.H., Shafiq, M. and Berhanu, G., 2011. Factors affecting students' quality of academic performance: a case of secondary school level. Journal of quality and technology management, 7(2), pp.1-14.

24. Fitsilis, P., Gerogiannis, V. and Anthopoulos, L., 2014. Ontologies for software project management: a review. Journal of Software Engineering and Applications, 7(13), p.1096.

25. Adams, J.D. and Jaffe, A.B., 1996. Bounding the effects of R\&D: an investigation using matched establishment-firm data(No. w5544). National bureau of economic research.

\section{AUTHORS PROFILE}

R. Velanganni, Assistant professor, Department Of Science \& Humanities, Bharath Institute of Higher Education and Research ,Chennai, India

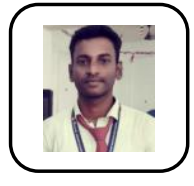

G. Santhoshkumar,

Assistant professor, Department Science 
Enhancing Labour Productivity by Introducing Usage of Limited Electrical Gadgets During Working Hours

Humanities, Bharath Institute of Higher Education and Research ,Chennai, India.

S. Robin, Assistant professor, Department Of Science \&

Humanities, Bharath Institute of Higher Education and

Research ,Chennai, India 